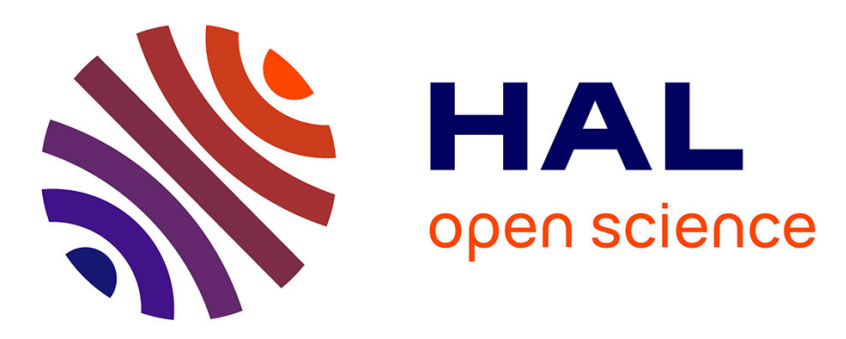

\title{
Application of polymer swelling by scCO2 to the synthesis of polymer/metal nanocomposites
}

Pauline Vitoux, Melanie Majimel, Thierry Tassaing, Jean-jacques Letourneau, Francois Cansell, Cyril Aymonier

\section{- To cite this version:}

Pauline Vitoux, Melanie Majimel, Thierry Tassaing, Jean-jacques Letourneau, Francois Cansell, et al.. Application of polymer swelling by scCO2 to the synthesis of polymer/metal nanocomposites. Solid State Phenomena, 2009, 151, pp.24-29. 10.4028/www.scientific.net/SSP.151.24 . hal-01668419

\author{
HAL Id: hal-01668419 \\ https://hal.science/hal-01668419
}

Submitted on 22 Mar 2019

HAL is a multi-disciplinary open access archive for the deposit and dissemination of scientific research documents, whether they are published or not. The documents may come from teaching and research institutions in France or abroad, or from public or private research centers.
L'archive ouverte pluridisciplinaire HAL, est destinée au dépôt et à la diffusion de documents scientifiques de niveau recherche, publiés ou non, émanant des établissements d'enseignement et de recherche français ou étrangers, des laboratoires publics ou privés. 


\title{
APPLICATION OF POLYMER SWELLING BY SCCO ${ }_{2}$ TO THE SYNTHESIS OF POLYMER/METAL NANOCOMPOSITES
}

\author{
Pauline Vitoux ${ }^{1, a}$, Mélanie Majimel ${ }^{1, b}$, Thierry Tassaing ${ }^{2, c}$, \\ Jean Jacques Letourneau ${ }^{3, d}$, François Cansell ${ }^{1, e}$ and Cyril Aymonier ${ }^{1, f}$ \\ ${ }^{1}$ Institut de Chimie de la Matière Condensée de Bordeaux, ICMCB-CNRS and ENSCPB, \\ Université Bordeaux 1, 87 Avenue du Docteur Albert Schweitzer, 33608 Pessac Cedex, France \\ ${ }^{2}$ Institut des Sciences Moléculaires, CNRS-Université Bordeaux 1, 351 Cours de la Libération, \\ 33405 Talence Cedex, France \\ ${ }^{3}$ Centre RAPSODEE, UMR CNRS 2392, Ecole des Mines d'Albi-Carmaux, Rte de Teillet, 81013 \\ Albi Cedex 09, France \\ avitoux@icmcb-bordeaux.cnrs.fr, ${ }^{b}$ mmajimel@icmcb-bordeaux.cnrs.fr, ct.tassaing@ism.u- \\ bordeaux1.fr, djean-jacques.letourneau@enstimac.fr, ${ }^{\mathrm{e}}$ cansell@enscpb.fr, \\ aymonier@icmcb-bordeaux.cnrs.fr
}

Keywords: inorganic nanoparticles, polymers, supercritical fluid, nanocomposite

\begin{abstract}
Polymer swelling by $\mathrm{scCO}_{2}$ was mainly studied to understand many industrial processes, especially in the field of pharmacy for drug delivery (impregnation) and also polymer processing by $\mathrm{CO}_{2}$-assisted extrusion. We have studied here another application of polymer swelling by $\mathrm{scCO}_{2}$ for the synthesis of nanocomposites. The selected model system was the direct synthesis of copper nanoparticles in a poly(ethylene glycol) matrix (PEG). The study of the formation of nanostructures in polymer matrix is constituted of three main steps: i) thermodynamical behaviour of the polymer $/ \mathrm{CO}_{2}$ system, ii) viscosity of the polymer/ $\mathrm{CO}_{2}$ system and iii) nucleation and growth of copper nanoparticles.

First, the thermodynamical behaviour of the $\mathrm{PEG} / \mathrm{CO}_{2}$ system was studied by in situ IR spectroscopy. This method gives accurate values of the polymer swelling by $\mathrm{scCO}_{2}$ but also of the $\mathrm{CO}_{2}$ sorption in the polymer. For example, at $40^{\circ} \mathrm{C}-15 \mathrm{MPa}$, the swelling of PEG is equal to $35 \%$ for a $\mathrm{CO}_{2}$ solubility of $23 \mathrm{wt} \%$. Secondly, we have developed an original falling ball viscometer for the determination of PEG viscosity as a function of $\mathrm{CO}_{2}$ density. A good knowledge of the polymer $/ \mathrm{CO}_{2}$ system is finally used for the control of formation of copper nanoparticles. This formation was followed by in situ UV - visible spectroscopy and characterized by transmission electron microscopy.
\end{abstract}

\section{Introduction}

Polymer swelling by $\mathrm{scCO}_{2}$ was mainly studied to understand many industrial processes (in pharmacy for drug delivery [1] or in polymer processing by $\mathrm{CO}_{2}$-assisted extrusion [2,3]). Curiously, the approach of polymer swelling by $\mathrm{scCO}_{2}$ was occasionally used to functionalize polymer matrixes with inorganic nanoparticles (NPs) to produce organic-inorganic nanocomposites [4-8]. For example, platinum/poly(4-methyl-1-pentene) (PMP) composites [4] have been obtained by impregnation and reduction of CODPtMe $e_{2}$ in presence or not of $\mathrm{CO}_{2}$ and $\mathrm{H}_{2}$. Palladium NPs have also been stabilized in dendritic structures [8].

Based on the numerous application fields of these organic-inorganic nanocomposites (automotive, aeronautic, pharmacy, chemistry...), we have developed a complete method using supercritical fluids to understand and control the formation of NPs in polymer matrixes. This method is mainly based on three steps:

i) thermodynamical behaviour of the polymer $/ \mathrm{CO}_{2}$ system

ii) viscosity of the polymer / $\mathrm{CO}_{2}$ system

iii) nucleation and growth of nanoparticles 
The selected system for the development of the method of formation of NPs in polymer matrix is a poly(ethylene glycol) matrix (PEG) nanostructured with copper NPs. In order to correlate nucleation and growth phenomena of copper nanoparticles formation with the thermodynamical behaviour of the PEG/CO $\mathrm{CO}_{2}$ system, we have studied successively: i) the swelling of PEG by $\mathrm{scCO}_{2}$ and the $\mathrm{CO}_{2}$ sorption in PEG by in situ IR spectroscopy, ii) the viscosity of PEG/CO mixture with an original falling ball viscometer and iii) the formation of copper NPs in the PEG matrix.

\section{Study of PEG Swelling by $\mathrm{scCO}_{2}$ with in situ IR Measurements}

Principle of the Experiments. Poly(ethylene glycol) is a semi crystalline polymer with a glass transition temperature of $-70^{\circ} \mathrm{C}$ and a melting temperature of $6^{\circ} \mathrm{C}$. PEG (Aldrich, France) with average molar mass of $400 \mathrm{~g} / \mathrm{mol}$ was used in this study.

The near infrared absorption experiments were performed using a home made stainless steel cell equipped with four cylindrical sapphire windows with a pathlength of $7 \mathrm{~mm}$ [9]. The heating of the cell was performed using cartridge heaters disposed in the periphery of the body of the cell. Thanks to a hydraulic pressurizing system, the pressure can be raised up to $50 \mathrm{MPa}$ with an absolute uncertainty of $\pm 0.1 \mathrm{MPa}$ and a relative error of $\pm 0.3 \%$.

The cell was filled with PEG and heated up to the desired temperature (Fig. 1a). Before heating, the cell was pumped under vacuum in order to remove any trace of water in the polymer. The spectra were recorded for the neat polymer. $\mathrm{CO}_{2}$ was then added up to the highest desired pressure (Fig. 1b). The system was kept under isobaric and isothermal conditions for a long period of time (from few hours at high temperatures up to 2 or 3 days at $40^{\circ} \mathrm{C}$ ) to reach the thermodynamical equilibrium (Fig. 1c). After recording the spectrum, the pressure was decreased to a lower value. For each pressure, the equilibrium was considered to be reached when no change of the spectral bands was noticed.

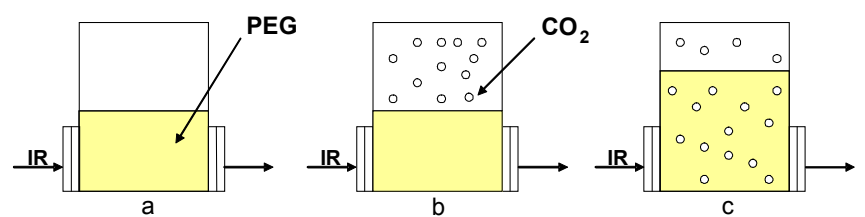

Fig. 1: Study of PEG swelling by $\mathrm{scCO}_{2}$ with in situ IR spectroscopy: a) IR measurement of PEG, b) injection of $\mathrm{CO}_{2}$ in the desired conditions, c) in situ measurement of PEG swelling by scCO$_{2}$

Results. IR spectra of PEG $[10,11]$ subjected to $\mathrm{CO}_{2}$ were recorded for a pressure of $15 \mathrm{MPa}$ and 3 temperatures: 40,100 and $150^{\circ} \mathrm{C}$.

The PEG swelling was determined from the variation of the maximum absorbance of a PEG peak centered at $4855 \mathrm{~cm}^{-1}$. Using the intensities of a band of $\mathrm{CO}_{2}$ sorbed in PEG (combination mode of the $\mathrm{CO}_{2}, v_{1}+2 v_{2}+v_{3}$ at $4960 \mathrm{~cm}^{-1}$ ), it is possible to determine the mass percentage of $\mathrm{CO}_{2}$ incorporated into the polymer using the following equations.

The concentrations of polymer before $\left(\mathrm{C}_{0}\right)$ and after exposure to $\mathrm{CO}_{2}(\mathrm{C})$ are given by the BeerLambert law (Eq. 1 and Eq. 2) [6].

$$
\begin{aligned}
& \mathrm{A}_{0}=\varepsilon \mathrm{C}_{0} 1 . \\
& \mathrm{A}=\varepsilon \mathrm{C} 1 .
\end{aligned}
$$

If $\mathrm{V}$ is the volume of the polymer before exposure to gas and $\mathrm{V}+\Delta \mathrm{V}$ the volume of the polymer during exposure to gas, it is possible to write (Eq. 3):

$$
\frac{\mathrm{C}_{0}}{\mathrm{C}}=\frac{\mathrm{V}+\Delta \mathrm{V}}{\mathrm{V}}=1+\frac{\Delta \mathrm{V}}{\mathrm{V}}=1+\mathrm{S}
$$


The swelling of the polymer is obtained by combining these equations (Eq. 4).

$$
\mathrm{S}=\frac{\mathrm{A}_{0}}{\mathrm{~A}}-1
$$

The concentration of $\mathrm{CO}_{2}$ incorporated into PEG $\left(\mathrm{C}_{\mathrm{CO} 2}\right)$ is given by the Beer-Lambert law using the integrated absorbance of the $v_{1}+2 v_{2}+v_{3} \mathrm{CO}_{2}$ band at $4960 \mathrm{~cm}^{-1}$. For a comparison with literature data, $\mathrm{CO}_{2}$ mass sorption incorporated into polymer matrix is given by Eq. 5 where $\rho_{\mathrm{po}} \mathrm{l}$ is the polymer density.

$$
\% \text { massCO} 2=\frac{\mathrm{C}_{2}{ }_{2}}{\mathrm{C}_{2}+\frac{\rho \text { pol }}{1+\mathrm{S}}}
$$

Fig. 2 shows the variations of PEG swelling and $\mathrm{CO}_{2}$ mass sorption in PEG at $15 \mathrm{MPa}$ for 3 temperatures $\left(40^{\circ} \mathrm{C}, 100^{\circ} \mathrm{C}\right.$ and $\left.150^{\circ} \mathrm{C}\right)$.

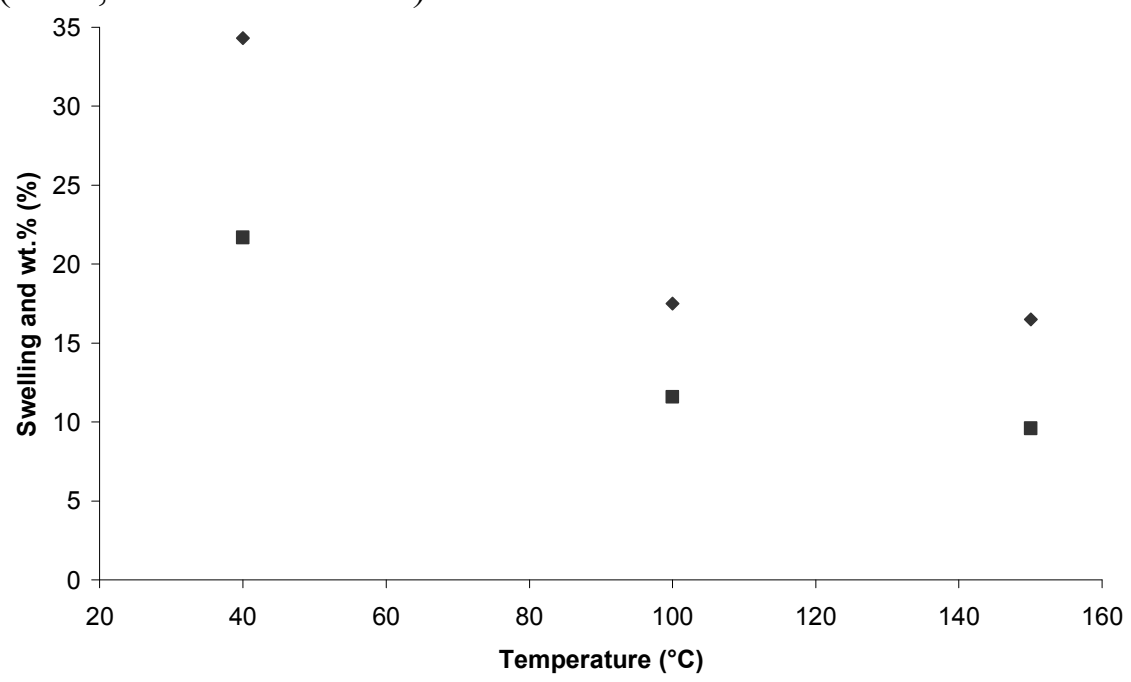

Fig. 2: Swelling of PEG ( $\downarrow)$ and $\mathrm{CO}_{2}$ weight percentage $(\square)$ as a function of temperature at $15 \mathrm{MPa}$

At constant pressure, an increase of temperature causes a decrease of both the weight percentage of $\mathrm{CO}_{2}$ incorporated into PEG and its swelling. This could be explained by a weakening of the $\mathrm{CO}_{2}-$ PEG interactions. The maximum swelling (35\%) and weight percentage of $\mathrm{CO}_{2}$ (about $22 \mathrm{wt} \%$ ) are obtained at $40^{\circ} \mathrm{C}-15 \mathrm{MPa}[10]$.

In addition to the study of the swelling of PEG by $\mathrm{scCO}_{2}$, viscosity has also been investigated. Indeed, it is an important parameter for the understanding of the nucleation and growth phenomena of NPs [12].

\section{Viscosity of the PEG/CO $\mathrm{CO}_{2}$ System}

Description of the Viscometer. The viscosity of $\mathrm{PEG} / \mathrm{CO}_{2}$ mixtures has been measured as a function of temperature $\left(100^{\circ} \mathrm{C}\right.$ and $150^{\circ} \mathrm{C}$ ) and pressure (up to $20 \mathrm{MPa}$ ) with an original falling ball viscometer. It is important to underline that it is not easy to perform viscosity measurements under pressure and temperature. The principle of the viscometer consists in observing the fall of a bead in an open tube immersed in a homogeneous medium (here PEG $+\mathrm{CO}_{2}$ ) and in measuring the time of its fall (Fig. 3).

Sapphire windows allow the lighting of the inside of the enclosure and the detection of the fall of the bead in the tube by a digital camera. The tube diameter depends on the diameter of the bead and 
allows a restricted flow fall of the bead in the fluid. Here, the tube has a diameter equal to $2.17 \mathrm{~mm}$ for a diameter of alumina bead of $2 \mathrm{~mm}$.

In a typical experiment, the glass vessel is filled with the polymer. The enclosure is heated at the desired temperature and $\mathrm{CO}_{2}$ is added up to the desired pressure. Agitation allows equilibrium to be reached faster. The bead distributor is operated and the fall of the bead is recorded thanks to the camera.

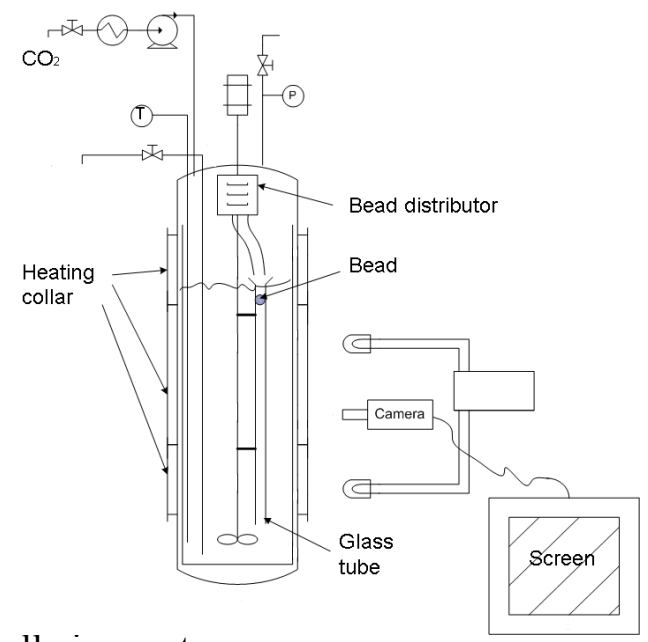

Fig. 3: Scheme of the falling ball viscometer

By using the classical correlation for the friction factor $(\mathrm{f}=16 / \mathrm{Re})$ for flow in tubes, the viscosity can be estimated in measuring the terminal falling velocity of the bead. This value has to be corrected by the way of a simulation (COMSOL $\left.{ }^{\circledR}\right)$ or a correlation which takes into account the specific form of the velocity distribution near the bead.

Results. Results are presented in fig. 4.

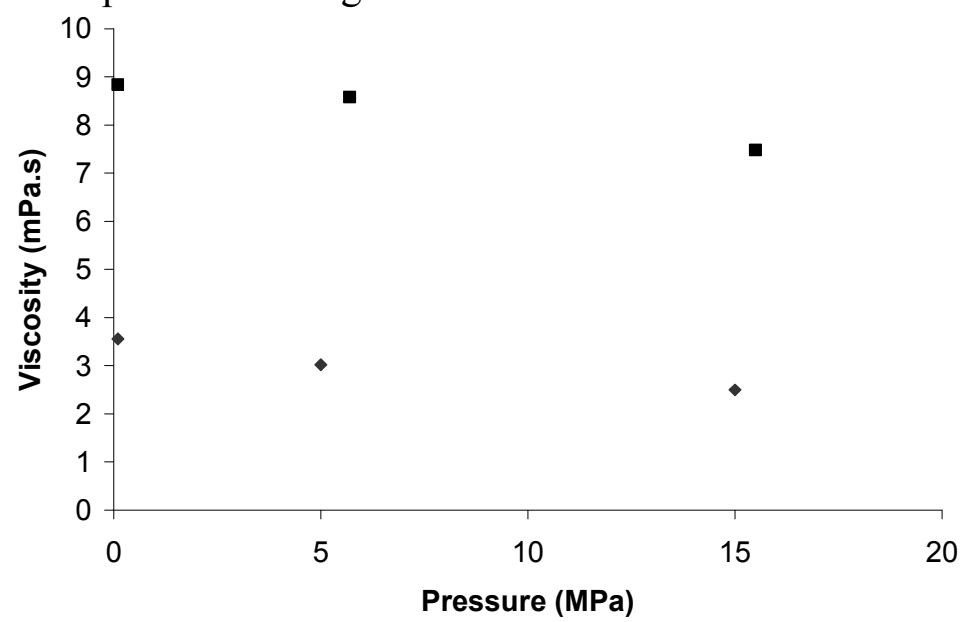

Fig. 4: Evolution of PEG viscosity saturated by $\mathrm{CO}_{2}$ at $100^{\circ} \mathrm{C}(\mathbf{\square})$ and $150^{\circ} \mathrm{C}(\bullet)$.

As expected, incorporation of $\mathrm{CO}_{2}$ into PEG decreases its viscosity. Indeed, when pressure increases, $\mathrm{CO}_{2}$ wt.\% incorporated in polymer matrix increases and the volume of the mixture increases. This leads to a decrease of the viscosity of the 'PEG/ $\mathrm{CO}_{2}$ 'mixture.

Formation of Copper NPs into the PEG Matrix

Experimental Procedure. A copper precursor (copper (II) acetylaceThis tonate, $\mathrm{Cu}(\mathrm{acac})_{2}$ ) is first mixed with the PEG. The reactor is charged with the solution. Then, the system is heated and a $\mathrm{CO}_{2}$ (with or without $\mathrm{H}_{2}$ ) pressure is applied to obtain decomposition of the precursor in supercritical conditions. 
In situ measurements by UV-visible spectroscopy were also performed to study the kinetics of formation of the copper NPs. The same cell as for IR measurements was used with an UV-Visible source. We follow the apparition and the evolution of copper plasmon band between $500 \mathrm{~nm}$ and $600 \mathrm{~nm}$.

Results. Three series of experiments were performed: (a) decomposition in $\mathrm{scCO}_{2}$, (b) decomposition without $\mathrm{CO}_{2}$ and (c) decomposition in $\mathrm{scCO}_{2} / \mathrm{H}_{2}$ mixture. The duration of each experiment was $2 \mathrm{~h}$. High Resolution Transmission Microscopy was performed to characterize the composition, the size and size distribution of nanoparticles in the PEG matrix (figure 4).

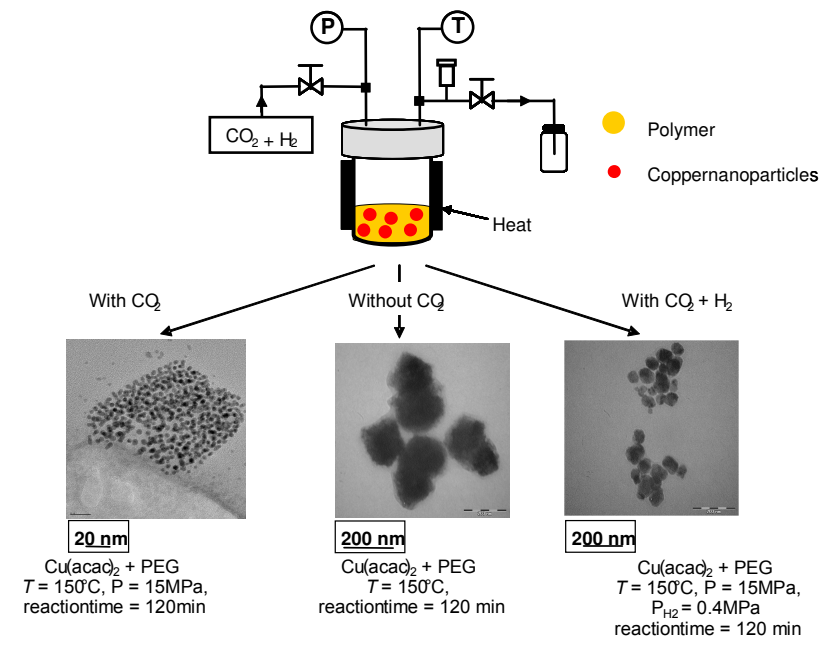

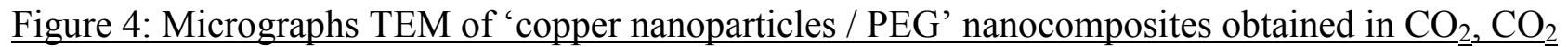
$\underline{/ \mathrm{H}_{2}}$ and without $\mathrm{CO}_{2}$ media

While copper nanoparticles ( $4 \mathrm{~nm}$ diameter), distributed in the polymer matrix, are obtained in $\mathrm{scCO}_{2}$, larger particles (200 $\mathrm{nm}$ diameter) are formed without $\mathrm{CO}_{2}$. This difference is attributed to the homogenization of the polymer/precursor solution in $\mathrm{scCO}_{2}$. In presence of $\mathrm{H}_{2}$, the size of the copper particles is observed to be around $50 \mathrm{~nm}$ which confirmed the faster decomposition of copper precursor in $\mathrm{CO}_{2} / \mathrm{H}_{2}$ medium comparing with $\mathrm{scCO}_{2}$. High Resolution Transmission Electron Microscopy shows the interest of decomposition in $\mathrm{scCO}_{2}$.

The evolution of the plasmon band of copper nanoparticles was followed by in situ UV-Visible spectroscopy. This method allows a determination of the decomposition temperature of the precursor through the formation of copper nanoparticles. Copper (II) acetylacetonate is decomposed at $200^{\circ} \mathrm{C}$ in $\mathrm{scCO}_{2}$ [13]. It appears from the UV-Visible study that, in PEG matrix saturated by $\mathrm{scCO}_{2}$, copper formation occurs at $110^{\circ} \mathrm{C}$ with or without $\mathrm{CO}_{2}$.

\section{Conclusions}

We have reported here a complete method for the optimisation of the synthesis of inorganic NPs in polymer matrixes, especially in this study, copper NPs in a PEG matrix. Thermodynamical behaviour of the PEG/CO $\mathrm{CO}_{2}$ system has been studied by in situ IR spectroscopy. We have obtained accurate values of $\mathrm{CO}_{2}$ mass percentage sorbed in $\mathrm{PEG}$. For example, at $40^{\circ} \mathrm{C}-15 \mathrm{MPa}$, the swelling of $\mathrm{PEG}$ is equal to $35 \%$ for a $\mathrm{CO}_{2}$ solubility of $22 \mathrm{wt} \%$.

By knowing the polymer swelling by $\mathrm{scCO}_{2}$, it is possible to determine the viscosity of PEG/CO solutions by an original falling ball viscosimeter. We have confirmed the reduction of PEG viscosity under $\mathrm{scCO}_{2}$ conditions. This study allows us to better understand the nucleation and growth phenomena of copper nanoparticles in polymer matrix. 
Finally, kinetics of copper nanoparticles formation in the polymer matrix was quantified by UV visible spectroscopy with the observation of the copper resonance plasmon band. The copper precursor was observed to be totally decomposed in a PEG matrix at $110^{\circ} \mathrm{C}$ after $1 \mathrm{~h}$ whereas a temperature equal to $200^{\circ} \mathrm{C}$ was necessary to obtain copper in $\mathrm{scCO}_{2}$. For example, copper nanoparticles, $4 \mathrm{~nm}$ in diameter and distributed in the polymer matrix, were obtained in a $\mathrm{scCO}_{2}$ medium.

All these parameters give an accurate knowledge of the nanocomposite system in order to optimize the synthesis (size and dispersion) of copper nanoparticles directly in the polymer matrix.

\section{ACKNOWLEDGMENTS}

The authors acknowledge DGA and CNRS for their financial support (PEPS07-33). ICMCB is a member of the PILA Network for high research and technological resources in multidisciplinar actions (http://web.univ-pau.fr/scf-PILA).

\section{REFERENCES}

[1] J. Richard and F. Deschamps, in: Colloïdal Polymers: Preparation and Biomedical Application, edited by A. Elaissari/Marcel Decker, NY, (2004).

[2] D. L. Tomasko, H. Li, D. Liu, X. Han, M. J. Wingert, L. J. Lee and K. W. Koelling: Ind. Eng. Chem. Res.Vol. 42 (2003), p. 6431

[3] J. Fages, in: Supercritical fluids and materials, edited by C. Aymonier, F. Cansell, and O. Fouassier, (2007)

[4] J. J. Watkins, T. J. McCarthy: Chem. Mater. Vol. 17 (2005), p. 560

[5] C. Aymonier, A. Loppinet-Serani, H. Reveron, Y. Garrabos and F. Cansell: J. Supercrit. Fluids. Vol. 38(2) (2006), p. 242

[6] S. Yoda, A. Hasegawa, H. Suda, Y. Uchimaru, K. Haraya, T. Tsuji and K. Otake: Chem. Mater.Vol. 16 (2004), p. 2363

[7] E.Said-Galiyev, L. Nikitin, V. Volkov, A. Khokhlov and K. Schaumburg: Ind. Eng. Chem. Res.Vol. 39 (2000), p. 4891

[8] S. Moisan, V. Martinez, P. Weisbacker, F. Cansell, S. Mecking and C. Aymonier: J. Am. Chem. Soc.Vol. 129 (34) (2007), p 10602

[9] V. Martinez, S. Mecking, T. Tassaing, M. Besnard, S. Moisan, F. Cansell and C. Aymonier: Macromolecules Vol. 39 (2006), p.3978

[10] P. Vitoux, F. Cansell, T. Tassaing, J. J. Letourneau and C. Aymonier: submitted to J. Phys. Chem. B, in press.

[11] T. Guadagno and S. Kazarian: J. Phys. Chem. B. Vol.10 (37) (2004), p.13995

[12] A. Erriguible, F. Marrias, F. Cansell and C. Aymonier: J. Supercrit. Fluids, in press.

[13] V. Pessey, R. Garriga, F. Weill, B. Chevalier, J. Etourneau and F. Cansell: J. Mater. Chem. Vol. 20 (2001), p. 289 